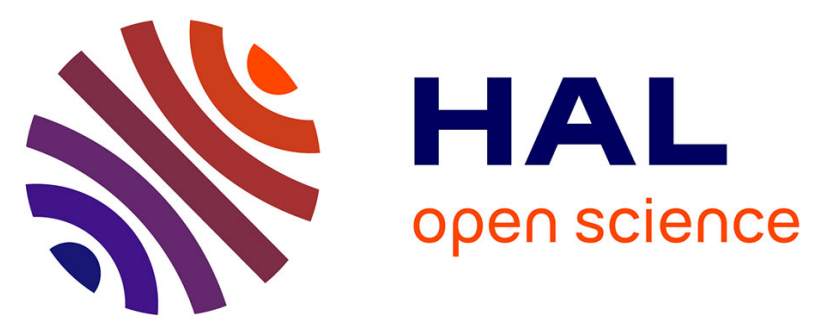

\title{
Cav1.4 calcium channels control cytokine production by human peripheral Th17 cells and psoriatic skin-infiltrating $\mathrm{T}$ cells
}

Marion Mars, Isabelle Néant, Catherine Leclerc, Stéphanie Bosch, Christian Rouviere, Marc Moreau, Simon Lachambre, Carle Paul, Marie Tauber, Eléonore Gravier, et al.

\section{To cite this version:}

Marion Mars, Isabelle Néant, Catherine Leclerc, Stéphanie Bosch, Christian Rouviere, et al.. Cav1.4 calcium channels control cytokine production by human peripheral Th17 cells and psoriatic skininfiltrating T cells. Journal of Allergy and Clinical Immunology, In press, 149 (4), pp.1348-1357. 10.1016/j.jaci.2021.09.030 . hal-03358572

\section{HAL Id: hal-03358572 \\ https://hal.science/hal-03358572}

Submitted on 29 Sep 2021

HAL is a multi-disciplinary open access archive for the deposit and dissemination of scientific research documents, whether they are published or not. The documents may come from teaching and research institutions in France or abroad, or from public or private research centers.
L'archive ouverte pluridisciplinaire HAL, est destinée au dépôt et à la diffusion de documents scientifiques de niveau recherche, publiés ou non, émanant des établissements d'enseignement et de recherche français ou étrangers, des laboratoires publics ou privés. 


\section{Cav1.4 calcium channels control cytokine production by human peripheral Th17-cells} and psoriatic skin-infiltrating $T$ cells

Marion Mars, $\mathrm{MSc}^{1}$, Isabelle Néant, $\mathrm{PhD}^{2}$, Catherine Leclerc, $\mathrm{PhD}^{2}$, Stéphanie Bosch, $\mathrm{MSc}^{2}$, Christian Rouviere, $\mathrm{PhD}^{2}$, Marc Moreau, $\mathrm{PhD}^{2}$, Simon Lachambre, $\mathrm{MSc}^{1}$, Carle Paul, MD,

$\mathrm{PhD}^{3}$, Marie Tauber, $\mathrm{MD}^{1,3}$, Eléonore Gravier, $\mathrm{MSc}^{4}$, Clara Douzal, $\mathrm{MSc}^{4}$, Hélène Duplan, $\mathrm{PhD}^{4}$, Marine Babin, $\mathrm{MSc}^{4}$, Alexia Brocario, $\mathrm{MSc}^{4}$, Marie-Dominique Thouvenin, $\mathrm{MD}^{4}$, JeanCharles Guéry, $\mathrm{PhD}^{1}$, Daniel Redoules, $\mathrm{PhD}^{5}$, Fabrice Lestienne, $\mathrm{MSc}^{4}$, Lucette Pelletier, $\mathrm{MD}$, $\mathrm{PhD}^{1}$, Magali Savignac, $\mathrm{PhD}^{1}$

${ }^{1}$ Toulouse Institute for Infectious and Inflammatory Diseases (Infinity) INSERM UMR1291 Centre National de la Recherche Scientifique UMR5051, University Paul Sabatier Toulouse III, F-31024 Toulouse, France

${ }^{2}$ Centre de Biologie du Développement, Centre de Biologie Intégrative, Université de Toulouse, CNRS, UPS, F-31062, Toulouse, France

${ }^{3}$ Dermatology Department, Larrey Hospital, University of Toulouse, Toulouse, France.

${ }^{4}$ Centre R\&D Pierre Fabre DermoCosmétique, 3 avenue Hubert Curien 31035 Toulouse, France ${ }^{5}$ Laboratoires Dermatologiques Avène, Les Cauquillous 81500 Lavaur, France

\section{Corresponding authors}

Magali Savignac, Toulouse Institute for Infectious and Inflammatory Diseases (Infinity), INSERM UMR1291, CHU Purpan, Place du Dr Baylac, 31024 Toulouse Cedex 3, France. Email: magali.savignac@inserm.fr. 
9

\section{Sources of funding}

This work was supported by the French National Institute for Health and Medical research (INSERM) and by Pierre Fabre Dermo-Cosmétique (PFDC). The funding body had no role in the design and conduct of the study, data collection, data management, data analysis and interpretation, writing the manuscript, or decision to submit results.

\section{Total word count}

3918 words (Introduction through Discussion only). 


\section{Abstract}

Background: Type-17 inflammation characterizes psoriasis, a chronic skin disease. As several inflammatory cytokines contribute to psoriasis pathogenesis, inhibiting the simultaneous production of these cytokines in Th17-cells may be beneficial in psoriasis. We found that $\mathrm{Ca}_{\mathrm{v}} 1.4$, encoded by $C A C N A 1 F$, was the only $\mathrm{Ca}_{\mathrm{v}} 1$ calcium channel expressed in Th17-cells. Objective: We investigated the role of $\mathrm{Ca}_{\mathrm{v}} 1.4$ expression in early Th17-activation events and effector functions, as well as its association with Th17 signature genes in lesional psoriatic (LP) skins. Methods: Transcriptional gene signatures associated with CACNA1F expression were examined in LP skins by RT-PCR and in situ hybridization. $\mathrm{Ca}_{\mathrm{v}} 1$ inhibitor and/or shRNA lentivectors were used to assess the contribution of $\mathrm{Ca}_{\mathrm{v}} 1.4$ on Th17 activation and effector functions in a 3D skin reconstruction model. Results: CACNA1F expression correlated with inflammatory cytokine expression that characterizes LP skins and was preferentially associated with $R O R C$ expression in $\mathrm{CD}^{+}{ }^{+}$and $\mathrm{CD}^{-}$cells from LP biopsies. Nicardipine, a $\mathrm{Ca}_{\mathrm{v}} 1$ channel antagonist, markedly reduced inflammatory cytokine production by Th17-cells from blood or LP skin. This was associated with decreased TCR-induced early calcium events at cell membrane and proximal signaling events. The knockdown of $\mathrm{Ca}_{\mathrm{v}} 1.4$ in Th17-cells impaired cytokine production. Finally, $\mathrm{Ca}_{\mathrm{v}} 1$ inhibition reduced the expression of the keratinocyte genes characteristic of Th17-mediated psoriasis inflammation in human skin equivalents. Conclusion: $\mathrm{Ca}_{\mathrm{v}} 1.4$ channels promote Th17-cell functions both at the periphery and in inflammatory psoriatic skin. Clinical implication: These data open a new field of therapy based on the development of drugs that inhibit $\mathrm{Ca}_{\mathrm{v}} 1.4$ calcium channels in the treatment of psoriasis. 


\section{Capsule Summary}

$\mathrm{Ca}_{\mathrm{v}} 1.4$ calcium channels selective for Th17 among effector T-cells are detected in skin psoriasis lesions and their inhibition reduces inflammatory cytokine production, opening a new field in psoriasis treatment.

\section{Key words}

Psoriasis, calcium channels, $\mathrm{Ca}_{\mathrm{v}} 1.4$, inflammatory cytokine, Th17 cells, TCR activation 


\section{Abbreviations}

61 AD: atopic dermatitis

$62 \mathrm{Ca}^{2+}:$ calcium

63 CsA: ciclosporin A

64 DC: dendritic cells

65 ECE: Elementary calcium events

66 GMFI: geometric mean fluorescence intensity

67 IHF: immunohistofluorescence

68 ISH: in situ hybridization

69 HD: healthy donor

70 LP: lesional psoriasis skin

71 NLP: non-lesional psoriasis skin

PBMC: peripheral blood mononuclear cell

PP: psoriasis patient

SE: skin equivalent 


\section{Introduction}

Psoriasis is a chronic inflammatory skin disease frequently associated with comorbidities, including arthritis, cardiometabolic disease, and a high emotional burden. It affects $2-3 \%$ of the world's population. The skin lesions present as erythematous scaly patches characterized by keratinocyte hyperproliferation and infiltration of the epidermis and dermis by inflammatory cells $^{1,2}$. Psoriasis results from the abnormal dialog between innate and adaptive immune cells, with an important role for T-helper 17 (Th17) cells ${ }^{3}$. Skin injury causes cell death and the release of self DNA-anti-microbial products such as LL37, which can activate plasmacytoid dendritic cells (DC) in the skin, resulting in interferon $\alpha$ (IFN $\alpha$ ) production and DC activation. Activated DCs migrate into the draining lymph node cells, where they polarize a population of self-reactive $\mathrm{CD}^{+}{ }^{+} \mathrm{T}$ lymphocytes producing interleukin (IL) 17, IL22, IFN $\gamma$ and tumor necrosis factor $\alpha(\mathrm{TNF} \alpha)$ through the secretion of IL23 mainly and IL12 ${ }^{4}$. These effector T-cells are recruited into the skin and produce inflammatory cytokines that induce keratinocyte proliferation and promote a positive feedback loop between the epithelial and immune cells, resulting in sustained inflammation ${ }^{3,5}$.

In accordance with this pathophysiological scheme, targeting the TNFa/IL23/IL17 cytokine axis is effective in the treatment of psoriasis $^{6-8}$. Although neutralizing anti-cytokine antibodies are protective in psoriasis, they present some disadvantages in terms of cost, administration route, and potential adverse events ${ }^{9,10}$. As Th17-derived cytokines are key effectors of psoriasis pathogenesis ${ }^{11}$, developing new therapies to reduce their productions could be beneficial in psoriasis.

In this context, we focused on the singularities of signaling pathways that control cytokine production in T-helper cells. We previously reported the discriminative expression of $\mathrm{Ca}_{v} 1$ calcium $\left(\mathrm{Ca}^{2+}\right)$ channel family members in different $\mathrm{T}$-cell populations ${ }^{12-14} \cdot \mathrm{Ca}_{\mathrm{v}} 1$ channels are a multi-protein complex composed of a pore-forming $\alpha 1$ subunit encoded by four genes 
(CACNA1S, CACNA1C, CACNA1D and CACNAIF encoding for the $\mathrm{Ca}_{\mathrm{v}} 1.1$ to $\mathrm{Ca}_{\mathrm{v}} 1.4$ channels, respectively), and auxiliary subunits $\beta$ and $\alpha 2-\delta$ (each encoded by four genes) ${ }^{15}$. In T lymphocytes, $\mathrm{Ca}_{\mathrm{v}} 1$ expression is plastic depending on their activation and differentiation status ${ }^{13,14,16}$. The $\mathrm{Ca}_{\mathrm{v}} 1.2$ and $\mathrm{Ca}_{\mathrm{v}} 1.3$ channels are selectively expressed in mouse and human Th2-cells ${ }^{12-14}$ and $\mathrm{Ca}_{v} 1.4$ is the only $\mathrm{Ca}_{\mathrm{v}} 1$ calcium channel to be expressed in Th17 cells from the peripheral blood of healthy donors (HD) ${ }^{14}$. Nicardipine, a $\mathrm{Ca}_{v} 1$ channel antagonist, decreased TCR-induced IL17A production by human Th17 $\left(\mathrm{CCR}^{+}\right)$cells ${ }^{14}$.

In the present study, we highlighted the presence of $\mathrm{Ca}_{\mathrm{v}} 1.4$ calcium channels in $\mathrm{ROR} \gamma \mathrm{t}^{+}$ $\mathrm{CD}^{+} \mathrm{T}$ cells from lesional psoriatic (LP) skin biopsies. $\mathrm{Ca}_{\mathrm{v}} 1$ inhibition dampened inflammatory cytokine production by Th17, regardless of their origin (blood or LP). Ca 1 channels acted early during Th17 activation contributing to the elementary $\mathrm{Ca}^{2+}$ events (ECE) preceding the global $\mathrm{Ca}^{2+}$ response. Finally, the $\mathrm{Ca}_{\mathrm{v}} 1$ blocker, nicardipine was beneficial in a 3D model of psoriasis-like reconstructed skin induced by the infiltration of activated Th17cells. 


\section{Methods}

\section{Healthy donors and patients}

This study complied with the ethical principles of the Declaration of Helsinki and with applicable French regulations. All human participants provided written informed consent. PBMCs from blood of anonymous, healthy donors (HD, 18 to 65 year-old male) were from the Toulouse blood transfusion center (Etablissement Français du Sang). Study (n²016-A0086348) from psoriasis patients (PP) and atopic dermatitis (AD) patients were accepted by the Committee for the Protection of Persons in the South-West and Overseas France III (Bordeaux) and The National Agency for the Safety of Medicines and Health Products (ANSM). For more details see the Online Repository.

\section{Th17 cell sorting and expansion}

From PBMC, CD4 ${ }^{+} \mathrm{CXCR}^{-} \mathrm{T}$ cells were enriched using EasySep ${ }^{\mathrm{TM}}$ Human Th17 Cell Enrichment Kit (STEMCELL Technologies). Then, CD4 ${ }^{+}$CD45RACCR6 ${ }^{+}{ }^{-}{ }^{-}{ }^{-} 3^{-}$(Th17) cells were cell sorted on a FACS Aria cell sorter (BD Biosciences). Cells $\left(0.2 \times 10^{6}\right)$ were expanded during 14 days with ImmunoCult ${ }^{\mathrm{TM}}$ Human CD3/CD28/CD2 T Cell Activator (STEMCELL) in Immunocult-XF (STEMCELL) medium containing IL2 (5 ng/mL), anti-IFN $\gamma$ antibody ( $5 \mu \mathrm{g} / \mathrm{ml}$, B27, BD Biosciences, to limit Th1 bias) and etanercept $(10 \mu \mathrm{g} / \mathrm{ml}$, to favor cell proliferation).

\section{Total internal reflection fluorescence (TIRF) microscopy}

Cells were loaded with $5 \mu \mathrm{M}$ Fluo-5-AM in culture medium containing 5\% heat-inactivated FBS and $100 \mu \mathrm{M}$ EGTA-AM (buffering $\mathrm{Ca}^{2+}$ at the channel mouth) for 30 minutes at $37^{\circ} \mathrm{C}$. After washing and plating cells in medium, we recorded elementary calcium events (ECE) at 
139 the cell membrane every $2 \mathrm{~ms}$ before and after stimulation with ImmunoCult ${ }^{\mathrm{TM}}$ Human CD3/CD28 T Cell Activator in presence or not of $10 \mu \mathrm{g} / \mathrm{ml}$ of nicardipine. We analyzed spatiotemporal fluorescence changes expressed as F/F0, the number of opened channels and the ECE opening frequencies. Complete procedures are given in the Online Repository.

Cytometry, calcium measurements, ELISA, western-blotting, qPCR, immunohistofluorescence (IHF) and in situ hybridization (ISH) on skin sections, Th17cell transduction with shRNA, T-cell recovery and amplification from LP biopsies, the generation of human inflammatory psoriasis skin equivalents populated with Th17 cells, murine imiquimod-induced psoriasis like model and statistical analyses were detailed in the Online Repository. 


\section{Results}

\section{CACNA1F expression, encoding the Cav1.4 calcium channel, expression is higher in} lesional psoriatic compared with non-lesional psoriatic or atopic dermatitis biopsies

We first characterized gene expression profile in lesional (LP) versus non-lesional (NLP) psoriatic biopsies and for comparison we included lesional atopic dermatitis (AD) biopsies. As expected, the LP biopsies were characterized by the upregulation of genes known to have a pathological role in psoriasis, including genes encoding the cytokines related to the IL17/IL22 axis, (IL17A, IL26, IL23A, IFNG, CSF2, IL22, ILO), chemokines (CCL20 and CXCL8) involved in both Th1/ Th17 lymphocytes and neutrophil recruitment, and skin barrier function (elafin (PI3), ß-defensin2 (DEFB4B), late cornified envelop (LCE3A), psoriasin (S100A7), MPR6 (S100A8), mKi67, keratin16 (KRT16) and involucrin (IVL)). These genes were significantly more expressed in LP than in NLP skins (Figure 1A R1 and see Table E1 in the Online repository) and in $\mathrm{AD}$ biopsies for most of them (Figure 1A R1 and see Table E2 in the Online repository). The AD biopsies were characterized by the upregulation of genes involved in type 2-cell function/recruitment (IL13, CCL26, carbonic anhydrase 2 (CA2) and neural EGFL like 2 (NELL2)), (Figure 1A R1 and see Table E2 in the Online repository). Hierarchical clustering based on gene expression levels showed two clusters with respect to inflammation status: one containing the LP and AD biopsies and the other the NLP biopsies and two AD samples with low levels of anti-microbial peptide expression.

We observed significant $C A C N A 1 F$ overexpression in the LP versus NLP or AD skin (four and five-fold, respectively), (Figure 1B R1). The cytokines (IL17A, IFNG, and IL26) expression were significantly upregulated in LP compared with NLP and AD samples (Figure E1A R1 in the Online repository), and the expression of $C A C N A 1 F$ positively correlated with these cytokines (Figure 1C R1), but not in the different disease-states taken separately. 
In LP skin, Cav1.4 calcium channel is preferentially detected in $R O R C^{+}$compared with $R O R C^{-}$cells

Using in situ hybridization (ISH), we next analyzed whether $\mathrm{Ca}_{\mathrm{v}} 1.4$ expressing $\mathrm{ROR} \gamma \mathrm{t}^{+} \mathrm{CD} 4^{+}$ (Th17) lymphocytes can be detected in LP skins. CD4 ${ }^{+} \mathrm{T}$ cells co-expressing CACNAlF and RORC (encoding for the transcription factor ROR $\gamma \mathrm{t}$ ) mRNAs were detected in all LPs (Figure 1D R1). Among $C D 4^{+}$cells, which represented $21 \%$ (20.7 \pm 9.1$)$ of nucleated cells, $29 \%$ (28.5 $\pm 10.1)$ were $R O R C^{+}$(Figure 1D and 1E R1). CACNAlF was found in $47 \%(47.2 \pm 18.9)$ of $\mathrm{RORC}^{+} \mathrm{CD}^{+}$cells versus $28 \%$ (27.8 \pm 17.3 ) of $\mathrm{RORC}^{-} \mathrm{CD}^{+}$cells (Figure 1E R1). Thus, there was a strong enrichment in $C A C N A I F^{+}$cells among $R O R C^{+} C D 4^{+}$cells compared with $R O R C^{-}$ $C D 4^{+}$(Figure E1B R1 in the Online repository). Among the $C D 4^{-}$cells, $19 \%(19.2 \pm 10)$ were $R O R C^{+}$, with $40 \%$ (39.8 \pm 15.6$)$ being $C A C N A 1 F^{+}$versus $21 \%(21.2 \pm 10)$ of $C A C N A 1 F^{+}$ in $R O R C^{-}$(Figure 1E R1). As in the $\mathrm{CD4}^{+}$cells, there was an enrichment in $C A C N A 1 F^{+}$cells among $\mathrm{RORC}^{+} \mathrm{CD}^{-}$cells compared with $\mathrm{RORC}^{-} \mathrm{CD}^{-}$(Figure E1C R1 in the Online repository). There was a positive correlation between the percentage of $\mathrm{CD}^{+} \mathrm{RORC}^{+}$ $C A C N A 1 F^{+}$and $C D 4^{-} \mathrm{RORC}^{+} C A C N A 1 F^{+}$(Figure E1D R1 in the Online repository ), suggesting a robust association between $C A C N A 1 F$ and $R O R C$ gene expression within the same cells.

At the protein level, we confirmed the detection of cells co-labeled with anti-Cav 1.4 , anti-CD4 and anti-ROR $\gamma t$ antibodies in the dermis (Figure 1F R1). Notably, higher numbers of $\mathrm{Ca}_{\mathrm{v}} 1.4^{+} \mathrm{ROR} \gamma \mathrm{t}^{+} \mathrm{CD} 4^{+}$cells were associated with $\mathrm{T}$ cell clustering in LP skins (Figure 1F R1 and New Figure 1G R1). Cav1.4 staining was not detected in the epidermis.

TCR-induced cytokine production by T cells infiltrating psoriatic lesions depends on Cav1 channels 
To investigate the role of $\mathrm{Ca}_{\mathrm{v}} 1.4$ in LP skins, infiltrating T-cells were recovered and amplified by stimulation with anti-CD3/CD28/CD2 in the presence of IL2 and IL23, as previously described $^{17}$, (Figure 2A). Fourteen days later, all cells were $\mathrm{CD}^{+}$, dividing nearly equally into $\mathrm{CD}^{+}$and $\mathrm{CD}^{+} \mathrm{T}$ cells (Figure 2B). We defined Th1, Th1/Th17, and Th17 cells as $\mathrm{CD}^{+}{ }^{+} \mathrm{CD} 45 \mathrm{RA}^{-}$cells that were $\mathrm{CXCR}^{+}{ }^{+} \mathrm{CCR} 6{ }^{-}, \mathrm{CXCR}^{+}{ }^{+} \mathrm{CRR}^{+}$and $\mathrm{CXCR}^{-} \mathrm{CCR} 6^{+}$ respectively according to previous works ${ }^{18}$. Expanded skin T-cells were composed of Th17 (30\%), Th1/Th17 (30\%) and Th1 (20\%) cells (Figure 2C). Upon anti-CD3/CD28 stimulation, T cells produced IL17A, IL22, IFN $\gamma$ and TNFa (Figure 2D). Nicardipine, a $\mathrm{Ca}_{\mathrm{v}} 1$ channel antagonist (used at $10 \mu \mathrm{g} / \mathrm{ml}$, a concentration that inhibits $\mathrm{Ca}_{\mathrm{v}} 1$ function in human Th2 cells ${ }^{14}$ ) reduced the production of IL17A (36\%), IL22 (35\%), IFN $\gamma(27 \%)$ and TNF $\alpha(53 \%)$ upon TCR stimulation (Figure 2D and Figure E2A in the Online repository). Cytokine gene transcription depended on $\mathrm{Ca}_{\mathrm{v}} 1$ channels, as nicardipine inhibited the TCR-induced transcription of IL17A (52\%), IL22 (57\%) and at a lower level IFNG (37\%) and TNFA (27\%) (Figure 2E and see Figure E2B in the Online repository). In addition, IL17F and CSF2 transcript expressions induced by TCR-stimulation were reduced by nicardipine (by 54\% and $42 \%$ respectively, Figure 2E and Figure E2B in the Online repository). Altogether, these data suggest that TCR-induced cytokine expression and production were partially controlled by $\mathrm{Ca}_{\mathrm{v}} 1$ calcium channels in LP-infiltrating T-cells.

\section{TCR-induced cytokine transcription and production by Th17 cells expanded from healthy} and psoriatic patient PBMCs are also partially controlled by Cav1 channel activation Based on chemokine receptor expression, we showed that the only population to be significantly increased in PP compared with HD was the Th17 cells (see Figure E3 in the Online repository). To investigate the role of $\mathrm{Ca}_{\mathrm{v}} 1.4$ in Th17 cell functions of PP and HD, we set up a protocol of amplification to obtain sufficient Th17 cells from the peripheral blood. We 
sorted the Th17 cells $\left(\mathrm{CD}^{+}{ }^{+} \mathrm{CD} 45 \mathrm{RA}^{-} \mathrm{CCR} 6^{+} \mathrm{CXCR}^{-}\right)$and expanded them by antiCD3/CD28/CD2 stimulation for 14-21 days in the presence of IL2, anti-IFN $\gamma$ and anti-TNF $\alpha$ antibodies. The expanded Th17 cells still displayed their ability to produce IL17A, IL22, and IFN $\gamma$ (although at a lower level for the two latter cytokines) when compared with ex vivo production (see Figure E4A in the Online repository). The expression of $R O R C$ and CACNAIF remained detectable in expanded Th17-cells (see Figure E4B in the Online repository).

The Th17 cells from PP and HD produced IL17A, IL22, IFN $\gamma$, and TNF $\alpha$ after antiCD3/CD28 stimulation (Figure 3). Nicardipine decreased not only the percentage of cytokineproducing cells (Figure 3) but also the amount of cytokines per cells (GMFI) and in culture supernatants, and their transcription (see Figure E5 and E6 in the Online repository). The inhibitory effect of nicardipine on cytokines was similar in HD and PP, with respect to cytokine secretion, production, or transcription (see Figure E5 and E6 in the Online repository). Together, these results show that $\mathrm{Ca}_{v} 1 \mathrm{Ca}^{2+}$ channels contribute to optimal cytokine production by TCR-activated Th17 lymphocytes from HD and PP.

\section{Cav1 channels are involved in TCR-driven initial calcium events and transduction} signaling in Th17 cells

To demonstrate that $\mathrm{Ca}_{\mathrm{v}} 1$ channels play a role in the global $\mathrm{Ca}^{2+}$ response of $\mathrm{Th} 17$ cells, we analyzed changes in the intracellular $\mathrm{Ca}^{2+}$ concentration $\left(\left[\mathrm{Ca}^{2+}\right]_{\mathrm{i}}\right)$ induced by TCR stimulation of expanded Th17 cells from the peripheral blood of HD. As shown in Figure 4A-B, nicardipine strongly reduced the TCR-induced increase in $\left[\mathrm{Ca}^{2+}\right]_{\mathrm{i}}$. We also analyzed the potential role of $\mathrm{Ca}_{\mathrm{v}} 1$ channels in the regulation of endoplasmic reticulum (ER) $\mathrm{Ca}^{2+}$ stores and store-operated $\mathrm{Ca}^{2+}$ entry (SOCE) by examining the effect of nicardipine on the $\mathrm{Ca}^{2+}$ signal elicited by thapsigargin in the presence or absence of calcium in the extracellular medium. Nicardipine 
neither affected intracellular $\mathrm{Ca}^{2+}$ store release into the cytoplasm, nor SOCE resulting from the ER calcium depletion induced by thapsigargin (see Figure E7 in the Online repository). In order to deepen the role of $\mathrm{Ca}_{\mathrm{v}} 1$ channels in the influx of $\mathrm{Ca}^{2+}$ following TCR engagement, we developed total internal reflection fluorescence microscopy (TIRFM) imaging to record rapid $\mathrm{Ca}^{2+}$ changes close to the plasma membrane. This allows the imaging of peaks corresponding to spatiotemporal single elementary calcium events (ECE) likely due to the activity of one channel or a cluster of $\mathrm{Ca}^{2+}$ channels ${ }^{19}$. Under resting conditions, the expanded Th17-cells from the peripheral blood of HD displayed few ECEs and their number significantly increased by 1.82 fold after 2-10 seconds of stimulation with anti-CD3-biotin/streptavidin complexes (Figure 4C-E). In addition, the ECE opening frequency significantly increased by TCR stimulation (Figure 4F), suggesting that both an increase in the number of open channels and higher opening frequencies are responsible for initial TCR-driven localized $\mathrm{Ca}^{2+}$ fluxes. Nicardipine decreased the number of spontaneous ECEs in resting cells (Figure 4C-E) and precluded the increase in ECE numbers and opening frequencies upon TCR stimulation (Figure 4C-F). Thus, $\mathrm{Ca}_{\mathrm{v}} 1$ channels support early $\mathrm{Ca}^{2+}$ influx at the plasma membrane in both resting and TCR-activated Th17 cells, even before the global $\left[\mathrm{Ca}^{2+}\right]_{\mathrm{i}}$ rise.

We then studied the consequences of this early decrease in calcium entry after TCR engagement on proximal transduction signaling. The TCR-induced phosphorylated-tyrosine protein pattern (Figure 4G) and phosphorylation of the MAPKinase, ERK2, were decreased by nicardipine (Figure 4H). Nicardipine also inhibited the nuclear translocation of the $\mathrm{Ca}^{2+}$ dependent transcription factor, NFATc2 (Figure 4I). Altogether, these data suggest that $\mathrm{Ca}_{\mathrm{v}} 1$ channels control an early calcium entry after TCR engagement, which is essential for the full TCR-driven activation of Th17 cells.

\section{Knockdown of Cav1.4 decreases IL17A and IL22 production by Th17 cells}


As nicardipine antagonizes all $\mathrm{Ca}_{\mathrm{v}} 1$ channels, we tested the specific role of $\mathrm{Ca}_{\mathrm{v}} 1.4$ in $\mathrm{Th} 17$ functions by knocking down its expression using GFP reporter shRNAs. Th17-cells from the peripheral blood of HD transduced with gene-specific shRNAs resulted in a strong reduction of $C A C N A 1 F$ expression (50\%, Figure $4 \mathbf{J}$ ) associated with a reduction of $\mathrm{Ca}_{\mathrm{v}} 1.4$ channel at the protein level $(87 \%$, Figure $\mathbf{4 K})$ in $\mathrm{GFP}^{+}$sorted cells compared with cells transduced with control shRNA. We did not detect compensatory CACNA1C and CACNAID expression in the Th17 cells transduced with shRNAs against CACNA1F (Figure 4J). The decreased $\mathrm{Ca}_{\mathbf{v}} 1.4$ expression was associated with the reduced production of IL17A and IL22 after TCR stimulation by 55 and 59\%, respectively (Figure 4L). These data provide evidence for the selective role of $\mathrm{Ca}_{\mathrm{v}} 1.4$ in IL17A and IL22 production by Th17 cells.

Cav1 channels are involved in the development of psoriatic inflammation in a human 3D skin reconstruction model and in murine imiquimod-induced psoriasis like model

To study the role of $\mathrm{Ca}_{\mathrm{v}} 1$ channels in the pathogenesis of Th17 cells in psoriasis, we established a three-dimensional (3D) skin reconstruction model, in which the expression by keratinocytes of psoriasis inflammatory markers is induced by populating the skin with activated Th17cells ${ }^{20}$. To evaluate the role of $\mathrm{Ca}_{\mathrm{v}} 1$ channels in the development of psoriasis inflammation, nicardipine was added to Th17 cells before stimulation and on each day of the culture (Figure 5A). Ciclosporin A (CsA), used as a control, was only added the last two days of the culture, as previously described ${ }^{20}$. Activation of Th17 cells was confirmed by CD69 expression and was not modified by nicardipine (data not shown). Nicardipine did not prevent Th17 cells from migrating into skin equivalents (SE), as shown by the number of infiltrating $\mathrm{CD}^{+}{ }^{+} \mathrm{T}$-cells after four days of culture (Figure 5B-C). According to ${ }^{20}$, addition of Th17-cells did not modify the epidermis morphology, with no effect of nicardipine or CsA (see Figure E8 in the Online repository). Nicardipine tended to reduce IL17A production and significantly decreased IL22 
production (Figure 5D). The infiltration of Th17 cells in SE induced a significant increase in the expression of psoriasis-associated genes, such as KRT16, PI3, and DEFB4 (encoding for cytokeratin 16, elafin, and $\beta$-defensin 2, respectively), after four days of culture (Figure 5E). Nicardipine decreased the expression of these genes to the same level as CsA (Figure 5E). These data suggest that inhibition of $\mathrm{Ca}_{\mathrm{v}} 1$ channels can releave the psoriatic inflammation in a 3D skin reconstruction model, probably by acting on Th17-cells functions, in accordance with locally decreased IL17A and IL22 production.

Finally, we investigated the role of $\mathrm{Ca}_{\mathrm{v}} 1$ calcium channels in local lesions in murine imiquimod-induced psoriasis like model. We applied Imiquimod to the shaved back and on one ear of BALB/c mice that received or not intraperitoneal injections of nicardipine. As shown in the New Figure E9A R1 below, imiquimod-treated mice presented dermal inflammation and epidermal acanthosis compared with untreated mice, in treated-ear and -back skin (see New Figure E9A and 1B R1 in the Online repository) and a significant increase of IMQ-treatedear and -back skin thickness (see New Figure E9C R1 in the Online repository). The inhibition of $\mathrm{Ca}_{v} 1$ channels by nicardipine greatly reduced both dermal inflammation, epidermal acanthosis and decreased the ear and back-skin thickness in this experimental model. 


\section{Discussion}

This study aimed to investigate the singularities of the $\mathrm{Ca}^{2+}$ toolkit of human $\mathrm{Th} 17 \mathrm{CD} 4^{+} \mathrm{T}$ cell activation and its possible involvement in psoriasis, a Th17 skewed chronic skin disease. We focused on $\mathrm{Ca}_{\mathrm{v}} 1.4$, since this channel, which is present in naive $\mathrm{CD} 4^{+} \mathrm{T}$ cells, disappears upon activation and differentiation of effector human $\mathrm{T}$ cells, except in Th17 cells ${ }^{14}$. Our results showed a preferential association of $C A C N A 1 F$ with $R O R C$ expression in $\mathrm{CD}^{+}$and $\mathrm{CD}^{-}$cells, and the detection of $\mathrm{CD}^{+}{ }^{+} \mathrm{ROR} \gamma \mathrm{t}^{+} \mathrm{Ca}_{\mathrm{v}} 1.4^{+}$triple-positive cells in the LP skin dermis. The inhibition of $\mathrm{Ca}_{\mathrm{v}} 1$ channels decreased Th17 cytokine transcription and production. The $\mathrm{Ca}_{\mathrm{v}} 1$ channels acted early during Th17-cell activation, allowing optimal Th17 cell activation, as indicated by the effect of nicardipine on global early tyrosine phosphorylation, MAP Kinase activation and NFAT nuclear translocation. The $\mathrm{Ca}_{\mathrm{v}} 1.4$ knockdown decreased IL17A and IL22 production, supporting the role of this channel in the Th17-cells. Moreover, the $\mathrm{Ca}_{\mathrm{v}} 1$ channel blocker decreased psoriatic inflammation in a model of skin equivalent model populated with Th17 cells.

The expression of CACNA1F was higher in LP than in NLP or AD skin and correlated with the expression of the inflammatory cytokines ILI7A, IFNG, and IL26 only when the different groups (lesional and non-lesional psoriasis and atopic dermatitis) were analyzed together. Moreover, $C A C N A 1 F$ expression was enriched among $R O R C^{+}$over $R O R C^{-}$cells in both $\mathrm{CD}^{+}$and $\mathrm{CD}^{-}$dermis-infiltrating cells from PP. We did not check the expression of CACNA1F in the regulatory $\mathrm{T}$ cells, but these cells have been shown to turn into RORC expressing cells which produce IL17 in psoriatic skin ${ }^{21}$. The $\mathrm{Ca}_{\mathrm{v}} 1.4$ channel was also present in $\mathrm{RORC}^{+} \mathrm{CD}^{-}$cells (which might include CD8 T cells, neutrophils, and ILC3), supporting the role of $\mathrm{Ca}_{v} 1.4$ in the IL17-associated inflammatory axis ${ }^{22} \cdot \mathrm{Ca}_{v} 1.4$ expression was not observed in the epidermis, suggesting that the keratinocytes do not express this $\mathrm{Ca}^{2+}$ channel. In the dermis, $\mathrm{Ca}_{\mathrm{v}} 1.4$ was essentially found in inflammatory zones containing clusters of $\mathrm{CD}^{+}{ }^{+} \mathrm{T}$ cells. 
We expanded $\mathrm{T}$ cells from the biopsies and showed that they transcribed the pro-inflammatory cytokines IL17A, IL17F, IL22, IFNG, CSF2 and TNFA after TCR stimulation. Nicardipine, a $\mathrm{Ca}_{\mathrm{v}} 1$ channel antagonist, reduced both TCR-induced cytokine transcription and production by the $\mathrm{CD} 4^{+} \mathrm{T}$ cells infiltrating the PP skin. Although the $\mathrm{CD} 4^{+} \mathrm{T}$ cells were the main producers of IL17A and IL22 (the CD8 ${ }^{+}$T cells produced very few IL17A and IL22; data not shown), IFN $\gamma$ and TNF $\alpha$ were also produced by infiltrating $\mathrm{CD} 8^{+} \mathrm{T}$ cells, and nicardipine inhibited their production (not shown), in accordance with $\mathrm{Ca}_{\mathrm{v}} 1.4$ expression by the $\mathrm{CD}^{+} \mathrm{T}$ cells ${ }^{14}$. It is interesting to note the potential inhibitory action of nicardipine on all cytokines and in the majority of PPs, since these cytokines act synergistically and amplify the inflammatory loop in psoriatic skin inflammation ${ }^{23,24}$.

The $\mathrm{CCR}^{+} \mathrm{CXCR}^{-} \mathrm{CD}^{+} \mathrm{T}$ cells that expressed $\mathrm{RORC}$, the master switch transcription factor of Th17 cells, were the only subset to increase in the blood of PP compared to HD, in accordance with Blauvelt et al. ${ }^{22}$. The Th17 cells expressed CACNA1F and maintained this expression as well as their pattern of TCR-induced cytokine expression after expansion, indicating that they represent a valuable tool for studying Th17 functions. TCR stimulation of Th17 cells induced similar amounts of cytokines (transcription and production) from both PP and HD, which were inhibited to a similar extent by nicardipine. These data confirm the quantitative bias toward more Th17 cells in psoriasis and show that nicardipine reduced cytokine production by the Th17 cells obtained from the blood or even from inflamed tissues. Among the four $\mathrm{Ca}_{v} 1$ channels, $\mathrm{Ca}_{v} 1.4$ was the only $\mathrm{Ca}_{\mathrm{v}} 1$ channel expressed in the Th17 cells. Furthermore, the transduction of these cells with specific shRNA reduced inflammatory cytokine production. Altogether, these results support the role of $\mathrm{Ca}_{\mathrm{v}} 1.4$ in Th17-cell functions. Nicardipine decreased the transcription and production of all inflammatory cytokines tested, indicating that $\mathrm{Ca}_{\mathrm{v}} 1$ channels regulate common pathways upstream of cytokine gene transcription. The crucial role of $\mathrm{Ca}^{2+}$ in Th17 functions and their pathological potential ${ }^{25}$ 
explains why ciclosporin $\mathrm{A}$, which inhibits $\mathrm{Ca}^{2+}$-dependent phosphatase calcineurin, is effective in the treatment of $\mathrm{PP}^{26}$. Our investigations described an early role of $\mathrm{Ca}_{\mathrm{v}} 1$ channels during TCR activation as nicardipine fully abrogated early ECE induced by TCR stimulation and even decreased the few $\mathrm{Ca}^{2+}$ fluxes observed under resting conditions, leading to the conclusion that $\mathrm{Ca}_{\mathrm{v}} 1.4$ is involved in both $\mathrm{Ca}^{2+}$ homeostasis and the TCR response. Contrary to what is shown in murine naive $\mathrm{T}$ lymphocytes ${ }^{16}$, the $\mathrm{Ca}_{\mathrm{v}} 1.4$ channels do not regulate the intracellular $\mathrm{Ca}^{2+}$ stores nor the functionality of STIM/ORAI (SOCE) since the response to thapsigargin was not affected by nicardipine in human Th17 cells. However, nicardipine reduced the TCR-driven global $\mathrm{Ca}^{2+}$ response suggesting a link between the ECE and the cellular $\mathrm{Ca}^{2+}$ response and that the initial defect cannot be overcome to induce a full response in the absence of functional $\mathrm{Ca}_{\mathrm{v}} 1$ channels. It is conceivable that the ECEs locally modify the cell environment in the vicinity of the immune synapse allowing an optimal assembly of the TCR transduction machinery. This is in accordance with the role of local ECE preceding full TCR activation, required to initiate cell transduction, possibly through an effect on cytoskeleton rearrangement ${ }^{27,28}$. In murine $\mathrm{CD}^{+} \mathrm{T}$ cells, $\mathrm{Ca}_{\mathrm{v}} 1.4$ can associate with $\mathrm{p} 56^{\text {lck }}$ and vav1, which both play a key role in TCR-dependent signal transduction ${ }^{29}$. Nicardipine reduced the early profile of tyrosine phosphorylation, ERK2 activation and NFATc2 nuclear translocation, supporting the role of $\mathrm{Ca}_{v} 1$ channels in the initiation of global signal transduction. Our data suggest that $\mathrm{Ca}_{\mathrm{v}} 1.4$, which is known to activate at a relatively negative cell membrane potential, closer to the resting cell membrane potential than the other $\mathrm{Ca}_{\mathrm{v}} 1$ channels, could deliver $\mathrm{Ca}^{2+}$ in a very fast and localized manner facilitating the transduction machinery assembly. Several groups have shown that ORAI channels play a major role in the calcium response induced by TCR engagement in human pathogenic Th17 cells ${ }^{25,30}$, raising the question of the respective places of $\mathrm{Ca}_{\mathrm{v}} 1$ and Orai $\mathrm{Ca}^{2+}$ channels in Th17 cell $\mathrm{Ca}^{2+}$ signaling. TIRF experiments performed here favor the earliest involvement of $\mathrm{Ca}_{\mathrm{v}} 1$ channels in the initiation of $\mathrm{T}$-cell activation (very 
few seconds) followed by STIM/ORAI channel activation. Accordingly, the $\mathrm{Ca}_{\mathrm{v}} 1$ channels were described to act earlier than the ORAI channels following cell activation and to convey ten more calcium ions than the ORAI channels ${ }^{31}$.

In order to establish a potential beneficial use of $\mathrm{Ca}_{\mathrm{v}} 1.4$ inhibitors in the treatment of PP, we tested the effects of nicardipine on a human psoriatic inflammation 3D skin model populated with Th17 cells. Nicardipine did not prevent the migration of Th17 cells into the dermis, but it tended to diminish the expression of specific psoriasis keratinocyte markers with the same effects as CsA. As the cytokines produced by T cells appeared to be the main factor responsible for the psoriatic inflammatory phenotype ${ }^{20}$ and that nicardipine diminished IL17A and IL22 cytokines in the skin-equivalent infiltrated with Th17 cells, we propose that $\mathrm{Ca}_{\mathrm{v}} 1$ channel blockade reduced psoriatic gene expression by inhibiting the cytokine production by $\mathrm{T}$ cells. Moreover, we showed $\mathrm{Ca}_{\mathrm{v}} 1$ calcium channel blocker was beneficial in the treatment of psoriasis-like inflammation in mice since nicardipine inhibits the dermal inflammation, epidermal acanthosis and the ear and back-skin thickening in murine imiquimod-induced psoriasis like model.

The effect of nicardipine on the cytokine production by Th17 cells was partial, but affected all tested cytokines that participate in a positive feedback inflammatory loop ${ }^{26}$. $C A C N A 1 F$ was also associated with $R O R C$ expression in the $\mathrm{CD}^{-}$cells that also participate in psoriasis pathogenesis ${ }^{32}$. Therefore, targeting this channel might be beneficial to treat psoriasis. Finally, psoriasis is associated with cardiovascular comorbidities such as blood hypertension ${ }^{33}$; therefore, $\mathrm{Ca}_{\mathrm{v}} 1$ channel blockers could be also beneficial in this regard. 


\section{Acknowledgments}

413 We acknowledge support from F. Capilla at the histology facility (CREFRE), F. L'Faqihi, A.L. 414 Iscache, and V. Duplan at the flow cytometry facility (Infinity); S. Allart at the imaging facility 415 (Infinity). We thank Dr S. Laffont-Pradines for critical reading of the manuscript. We would 416 like to thank Editage (www.editage.com) for English language editing. 


\section{References}

1. Schön MP, Boehncke WH. Psoriasis. N Engl J Med 2005; 352:1899-912.

2. Nestle FO, Kaplan DH, Barker J. Psoriasis. N Engl J Med 2009; 361:496-509.

3. Boehncke WH, Schön MP. Psoriasis. Lancet 2015; 386:983-94.

4. Ehst B, Wang Z, Leitenberger J, McClanahan D, De La Torre R, Sawka E, et al. Synergistic induction of IL-23 by TNF $\alpha$, IL-17A, and EGF in keratinocytes. Cytokine 2020:155357.

5. Armstrong AW, Read C. Pathophysiology, Clinical Presentation, and Treatment of Psoriasis: A Review. Jama 2020; 323:1945-60.

6. Reich K, Papp KA, Blauvelt A, Langley RG, Armstrong A, Warren RB, et al. Bimekizumab versus ustekinumab for the treatment of moderate to severe plaque psoriasis (BE VIVID): efficacy and safety from a 52-week, multicentre, double-blind, active comparator and placebo controlled phase 3 trial. Lancet 2021; 397:487-98.

7. Girolomoni G, Strohal R, Puig L, Bachelez H, Barker J, Boehncke WH, et al. The role of IL-23 and the IL-23/T(H) 17 immune axis in the pathogenesis and treatment of psoriasis. $\mathrm{J}$ Eur Acad Dermatol Venereol 2017; 31:1616-26.

8. Krueger JG, Fretzin S, Suárez-Fariñas M, Haslett PA, Phipps KM, Cameron GS, et al. IL-17A is essential for cell activation and inflammatory gene circuits in subjects with psoriasis. J Allergy Clin Immunol 2012; 130:145-54.e9.

9. Wasilewska A, Winiarska M, Olszewska M, Rudnicka L. Interleukin-17 inhibitors. A new era in treatment of psoriasis and other skin diseases. Postepy Dermatol Alergol 2016; $33: 247-52$

10. Jullien D, Prinz JC, Nestle FO. Immunogenicity of biotherapy used in psoriasis: the science behind the scenes. J Invest Dermatol 2015; 135:31-8. 
11. Nash P. Inhibition of interleukins $17 \mathrm{~A}$ and $17 \mathrm{~F}$ in psoriatic arthritis. Lancet 2020; 395:395-6.

12. Gomes B, Cabral MD, Gallard A, Savignac M, Paulet P, Druet P, et al. Calcium channel blocker prevents T helper type 2 cell-mediated airway inflammation. Am J Respir Crit Care Med 2007; 175:1117-24.

13. Cabral MD, Paulet PE, Robert V, Gomes B, Renoud ML, Savignac M, et al. Knocking down Cav1 calcium channels implicated in Th2 cell activation prevents experimental asthma. Am J Respir Crit Care Med 2010; 181:1310-7.

14. Robert V, Triffaux E, Paulet PE, Guery JC, Pelletier L, Savignac M. Protein kinase Cdependent activation of CaV1.2 channels selectively controls human TH2-lymphocyte functions. J Allergy Clin Immunol 2014; 133:1175-83.

15. Catterall WA. Structure and regulation of voltage-gated Ca2+ channels. Annu Rev Cell Dev Biol 2000; 16:521-55.

16. Omilusik K, Priatel JJ, Chen X, Wang YT, Xu H, Choi KB, et al. The Ca(v)1.4 calcium channel is a critical regulator of $\mathrm{T}$ cell receptor signaling and naive $\mathrm{T}$ cell homeostasis. Immunity 2011; 35:349-60.

17. He X, de Oliveira VL, Keijsers R, Joosten I, Koenen HJ. Lymphocyte Isolation from Human Skin for Phenotypic Analysis and Ex Vivo Cell Culture. J Vis Exp 2016:e52564.

18. Acosta-Rodriguez EV, Rivino L, Geginat J, Jarrossay D, Gattorno M, Lanzavecchia A, et al. Surface phenotype and antigenic specificity of human interleukin 17-producing T helper memory cells. Nat Immunol 2007; 8:639-46.

19. Demuro A, Parker I. "Optical patch-clamping": single-channel recording by imaging Ca2+ flux through individual muscle acetylcholine receptor channels. J Gen Physiol 2005; 126:179-92. 
20. van den Bogaard EH, Tjabringa GS, Joosten I, Vonk-Bergers M, van Rijssen E, Tijssen HJ, et al. Crosstalk between keratinocytes and T cells in a 3D microenvironment: a model to study inflammatory skin diseases. J Invest Dermatol 2014; 134:719-27.

21. Bovenschen HJ, van de Kerkhof PC, van Erp PE, Woestenenk R, Joosten I, Koenen HJ. Foxp3+ regulatory $\mathrm{T}$ cells of psoriasis patients easily differentiate into IL-17A-producing cells and are found in lesional skin. J Invest Dermatol 2011; 131:1853-60.

22. Blauvelt A, Chiricozzi A. The Immunologic Role of IL-17 in Psoriasis and Psoriatic Arthritis Pathogenesis. Clin Rev Allergy Immunol 2018; 55:379-90.

23. Lowes MA, Suárez-Fariñas M, Krueger JG. Immunology of psoriasis. Annu Rev Immunol 2014; 32:227-55.

24. Baliwag J, Barnes DH, Johnston A. Cytokines in psoriasis. Cytokine 2015; 73:342-50. 25. Kaufmann U, Kahlfuss S, Yang J, Ivanova E, Koralov SB, Feske S. Calcium Signaling Controls Pathogenic Th17 Cell-Mediated Inflammation by Regulating Mitochondrial Function. Cell Metab 2019; 29:1104-18.e6.

26. Menter A, Gelfand JM, Connor C, Armstrong AW, Cordoro KM, Davis DMR, et al. Joint American Academy of Dermatology-National Psoriasis Foundation guidelines of care for the management of psoriasis with systemic nonbiologic therapies. J Am Acad Dermatol 2020; $82: 1445-86$.

27. Shi X, Bi Y, Yang W, Guo X, Jiang Y, Wan C, et al. Ca2+ regulates T-cell receptor activation by modulating the charge property of lipids. Nature 2013; 493:111-5.

28. Yi J, Balagopalan L, Nguyen T, McIntire KM, Samelson LE. TCR microclusters form spatially segregated domains and sequentially assemble in calcium-dependent kinetic steps. Nat Commun 2019; 10:277. 
29. Jha MK, Badou A, Meissner M, McRory JE, Freichel M, Flockerzi V, et al. Defective survival of naive CD8+ T lymphocytes in the absence of the beta3 regulatory subunit of voltagegated calcium channels. Nat Immunol 2009; 10:1275-82.

30. Kahlfuss S, Kaufmann U, Concepcion AR, Noyer L, Raphael D, Vaeth M, et al. STIM1mediated calcium influx controls antifungal immunity and the metabolic function of nonpathogenic Th17 cells. EMBO Mol Med 2020; 12:e11592.

31. Soboloff J, Rothberg BS, Madesh M, Gill DL. STIM proteins: dynamic calcium signal transducers. Nat Rev Mol Cell Biol 2012; 13:549-65.

32. Eberl G. RORgammat, a multitask nuclear receptor at mucosal surfaces. Mucosal Immunol 2017; 10:27-34.

33. Takeshita J, Grewal S, Langan SM, Mehta NN, Ogdie A, Van Voorhees AS, et al. Psoriasis and comorbid diseases: Epidemiology. J Am Acad Dermatol 2017; 76:377-90. 


\section{Author contributions}

MMa performed all the experiments. IN, CL, SB and CR performed ISH and HIF of psoriatic skin biopsies and confocal analysis. MMo and LP performed TIRF experiments. MMo developed software for TIRFM analysis and analyzed the number of open channels and their opening frequency. SL helped to analyze the nuclear translocation of NFAT. CP and MT designed and implemented the clinical study, recruited patients with psoriasis and atopic dermatitis. EG and CD developed analysis of qPCR data and performed heatmap. JCG, HD and DR contributed to the design of experiments and criticized the results. MB and MDT managed and supervised the clinical project. FL did the experimental design, performed and analysed the results of qPCR and criticized the results. LP and MS did the experimental design, analysed the results, and wrote the paper. MS supervised the work. All authors critically reviewed the manuscript. 


\section{Figure legends}

\section{New Figure 1 R1. Cav1.4 calcium channel expression in Th17-cells infiltrating psoriasis} skins

(A) Hierarchical gene expression heat map in lesional (LP), non-lesional (NLP) psoriasis and atopic dermatitis (AD) skins. (B) Violin plots showing CACNA $1 F$ expression. One symbol by patient; the median and the interquartile ranges are indicated. (C) Correlation between CACNAIF and cytokine expression in LP, NLP and AD skins. (D) Representative images with CD4 (red), RORC (green) and CACNA1F (white) encoding mRNAs by ISH of LP skins. (E) Quantifications of cell numbers per field as described in the Online Repository. (+/-) groups together cells that are positive or negative for the marker. Means \pm sem; one symbol by patient. (F) Representative images with CD4 (red), ROR $\gamma t$ (green) and $\mathrm{Ca}_{\mathrm{v}} 1.4$ (white) proteins by IHF of LP skins. Bar $=50 \mu \mathrm{m}$ for general view of skin section and $10 \mu \mathrm{m}$ for inserts. (New $\mathbf{G}) \mathrm{IHF}$ scores of LP skins. $0=$ any CD $4^{+}$ROR $\gamma \mathrm{t}^{+} \mathrm{Ca}_{\mathrm{v}} 1.4^{+}$cells in any zone; $1=$ one $\mathrm{CD}^{+} \mathrm{ROR} \mathrm{t}^{+}$ $\mathrm{Ca}_{\mathrm{v}} 1.4^{+}$cells in one zone; $2=$ several zones containing one $\mathrm{CD}^{+} \mathrm{ROR}^{+} \mathrm{t}^{+} \mathrm{Ca}_{\mathrm{v}} 1.4^{+}$cells $; 3=$ several zones containing at least three $\mathrm{CD}^{+} \mathrm{ROR} \mathrm{t}^{+} \mathrm{Ca}_{\mathrm{v}} 1.4^{+}$cells. Means \pm sem; one symbol by patient.

Figure 2. Cav1-dependent inflammatory cytokine production by T-cell-infiltrating lesional psoriasis skin

(A) Experimental procedure. (B) Lymphocyte frequencies after T-cell expansion. (C) Th17, Th1/Th17 and Th1-cell frequencies in expanded T-cells. (D-E) Cytokine production (ELISA, D) and expression (qPCR, E) in expanded T-cells after anti-CD3/CD28 stimulation with or without nicardipine. One symbol by patient. P values were determined by one-way ANOVA 
followed by Turkey's multiple comparison test. * $\mathrm{p}<0.05$; ** $\mathrm{p}<0.01 ; * * * \mathrm{p}<0.005$; $* * * * \mathrm{p}<0.0001$

\section{Figure 3. Cav1-dependent inflammatory cytokine production by peripheral blood Th17} cells

Th17 cells expanded from healthy donor (HD) and psoriasis patient (PP) blood were stimulated with anti-CD3/CD28/CD2 antibodies plus or minus (nicar) for $4 \mathrm{~h}$ before intracellular cytokine staining. Comparisons with one-way ANOVA followed by Turkey's multiple comparison tests. $* \mathrm{p}<0.05 ; * * * \mathrm{p}<0.005 ; * * * * \mathrm{p}<0.0001$

\section{New Figure 4. Cav1 channels contribute to TCR-induced $\left[\mathrm{Ca}^{2+}\right]_{i}$ rise and transduction} signaling in Th17 cells and knocking-down $C A C N A 1 F$ reduces Th17 cytokine production (A-B) HD Th17 cells were loaded with Fura2-AM and fluorescence was recorded before (F0) and after (F) TCR stimulation \pm nicardipine (nicar). (A) Mean \pm SEM from 50-100 cells from 3 HD. (B) the area under the curve. (C-F) 3-D images of ECE from Th17 cells loaded with Fluo-5AM (C), number of ECE (one symbol by cell; pool from $2 \mathrm{HD}$ ) (D), relative ECE number (E) and opening frequency (one symbol by ECE; 5-7 cells from 2 donors) (F). (New G-H) Th17 cells were stimulated with ImmunoCult ${ }^{\mathrm{TM}}$ Human CD3/CD28/CD2 T Cell Activator for 2 min (Stim) or not (NS) in presence or absence of nicardipine (nicar). Equal amounts of lysate proteins were blotted and probed with antibody against phosphorylated tyrosine (P-Tyr) (New G), P-ERK2 (New $\mathbf{H}$ ) or $\beta$-actin (Actin, loading control). Graphs show the quantification of staining intensities relative to actin intensity and to unstimulated samples of 3-4 donors. (New I) Th17 cells were stimulated with ImmunoCult ${ }^{\mathrm{TM}}$ Human CD3/CD28 T Cell Activator for 4 hours (Stim) or not (NS) in presence or absence of nicardipine (nicar). Nuclear translocation of NFATc2 is analyzed by confocal. Bar $=5 \mu \mathrm{m}(\mathbf{J}-\mathbf{L})$ HD Th17 cells were transduced with control 
(shCtr) or CACNA1F GFP reporter shRNAs. CACNA1 expression $(\mathbf{J}), \mathrm{Ca}_{\mathrm{v}} 1.4$ protein level $($ New K, Bar $=5 \mu \mathrm{m})$ and TCR-induced cytokine production $(\mathbf{L})$ in $\mathrm{GFP}^{+}$-sorted cells; 2-3 biological replicates from 3 experiments. P values were determined by Student's t-test (B, DF, New I and New K) and by paired Wilcoxon test (L). * p $<0.05 ; * * \mathrm{p}<0.01 ; * * * \mathrm{p}<0.005$; $* * * * \mathrm{p}<0.0001$

Figure 5. Antagonizing Cav1 channels diminishes cytokine and psoriasis-like gene expression in skin equivalent infiltrated by Th17 cells

(A) Experimental procedure. (B-C) Enumeration of $\mathrm{CD}^{+} \mathrm{T}$ cells 4 days after introducing Th17 cells under the skin equivalent (SE). The mean is indicated and the dotted line shows the background without T-cells. (D) IL17A and IL22 production 24h after Th17 cells introduction in SE Each point corresponds to one SE. (E) KRT16, PI3 and DEFB4B expression after 4 days of culture. P values were determined by paired Wilcoxon test $(\mathbf{D})$ and Student's t-test $(\mathbf{E})$. * $\mathrm{p}<0.05 ; * * \mathrm{p}<0.01 \mathrm{Bar}=50 \mu \mathrm{m}$. 